\title{
Comparative study of different methodologies to determine the exopolysaccharide produced by kefir grains in milk and whey
}

\author{
Pablo Sebastián RIMADA, Analía Graciela ABRAHAM* \\ Centro de Investigación y Desarrollo en Criotecnología de Alimentos, 47 y 116, 1900, La Plata, Argentina
}

(Received 27 November 2001; accepted 18 April 2002)

\begin{abstract}
Quantitative isolation of lactic acid bacteria exopolysaccharides (EPS) from dairy products is an important step to determine small amounts of EPS (between 25 and $890 \mathrm{mg} \cdot \mathrm{L}^{-1}$ ) in a medium that contains 30 to $50 \mathrm{~g} \cdot \mathrm{L}^{-1}$ of lactose. Kefir grains CIDCA AGK1 are able to produce an exopolysaccharide commonly known as kefiran when grown in milk and deproteinised whey. Different methodologies were compared for kefiran isolation from milk and whey fermented for $96 \mathrm{~h}$ at $20^{\circ} \mathrm{C}$ with $100 \mathrm{~g} \cdot \mathrm{L}^{-1}$ of kefir grains. Methods that included one or two steps of ethanol precipitation, one step of ethanol precipitation followed by dialysis, direct dialysis with membranes of different cut-off (1 000, 6000,12000$)$, and a TCA precipitation step were evaluated. The effect of a heat treatment of the milk on EPS recovery was also studied. The highest recovery of EPS was obtained when samples were heated as a first step of isolation. Methods that contained two steps of ethanol precipitation, one step of ethanol precipitation followed by dialysis or direct dialysis (molecular weight cut-off lower than 6000 to 8000 ) gave the highest values of polysaccharide concentration $\left(218 \mathrm{mg} \cdot \mathrm{L}^{-1}\right.$ of fermented milk and $247 \mathrm{mg} \cdot \mathrm{L}^{-1}$ of fermented whey). One step of ethanol precipitation did not completely eliminate residual lactose. EPS was partially lost when dialysis was carried out with membranes of cut-off of 12 000. About 50\% of EPS was lost when the method included a step of TCA precipitation. We conclude that polysaccharide quantified in milk and deproteinised whey fermented with kefir grains strongly depends on the isolation methodology used.
\end{abstract}

\section{Exopolysaccharide / EPS isolation / fermented milk / fermented whey / kefir}

Résumé - Étude comparative de différentes méthodologies pour déterminer la quantité d'exopolysaccharide produit par les grains de kefir dans le lait et le lactosérum. L'isolement quantitatif des exopolysaccharides (EPS) de bactéries lactiques à partir des produits laitiers est une étape importante pour déterminer de petites quantités d'EPS (entre 25 et $890 \mathrm{mg} \cdot \mathrm{L}^{-1}$ ) dans un milieu contenant entre 30 et $50 \mathrm{~g} \cdot \mathrm{L}^{-1}$ de lactose. Quand les grains de kefir AGK1 croissent dans le lait et dans le lactosérum deprotéiné, ils sont capables de produire un EPS généralement connu comme kefiran. Dans ce travail, nous avons comparé différentes méthodologies pour isoler le kefiran dans du lait et du lactosérum fermentés. Pour réaliser ces essais le lait et le lactoserum ont été fermentés pendant $96 \mathrm{~h} 20^{\circ} \mathrm{C}$ avec $100 \mathrm{~g} \cdot \mathrm{L}^{-1}$ de grains de kefir. Les différentes méthodologies pour déterminer l'EPS sont: la précipitation à l'ethanol, la précipitation à l'ethanol suivie d'une dialyse, une dialyse directe

* Correspondence and reprints

Tel.: 540221 4249287; fax: 540221 4890741; e-mail: aga@nahuel.biol.unlp.edu.ar 
avec membranes de différents seuils de coupure (1 000, 6 000, 12 000), et la précipitation au TCA. Nous avons aussi étudié l'effet de la chaleur dans le traitement du lait avant la récupération des EPS. De meilleurs résultats ont été obtenus après avoir chauffé les échantillons dans la première étape d'isolement. Les plus hautes valeurs de concentration d'EPS $\left(218 \mathrm{mg} \cdot \mathrm{L}^{-1}\right.$ de lait fermenté et $247 \mathrm{mg} \cdot \mathrm{L}^{-1}$ de lactosérum fermenté) ont été obtenues avec les méthodes utilisant soit deux précipitations successives à l'ethanol, soit une précipitation à l'ethanol suivie d'une dialyse, ou une dialyse directe (poids moléculaire de seuil de coupure inférieur à $6000-8000$ ). Notons qu'une seule précipitation à l'ethanol ne nous a pas permis d'éliminer complètement le lactose résiduel. La dialyse faite avec un seuil de coupure de 12000 ainsi que la précipitation au TCA entraînent une perte partielle des EPS synthétisés (jusqu'à $50 \%$ de perte avec la précipitation au TCA). En conclusion, nous pouvons dire que les valeurs de concentration d'EPS obtenues dans du lait et du lactosérum déproteiné fermenté avec les grains de kéfir dépendent fortement de la méthode d'isolement utilisée.

\section{Exopolysaccharide / isolement d'EPS / lait fermenté / lactosérum fermenté / kéfir}

\section{INTRODUCTION}

Interest in exopolysaccharide (EPS)producing lactic acid bacteria (LAB) has increased recently because these food grade organisms produce polymers important in determining the rheological properties of dairy products. When added to food products, polysaccharides function as thickeners, stabilisers, emulsifiers, gelling agents, and water-binding agents [6]. Some of these EPS, in addition to their ability to improve the texture of fermented products, exhibit advantageous biological properties, such as immunostimulation and antitumor and anti-ulcer activities [23, 24].

EPS derived from food starters are currently being considered as an alternative in the food industry to introduce the desired texture to foods. Dairy LAB are weak EPS producers. EPS production in milk depends strongly on the fermenting species even at strain level and ranges in concentration between 25 and $890 \mathrm{mg} \cdot \mathrm{L}^{-1}$ [4]. Optimisation of the growth environment (temperature, $\mathrm{pH}$, carbon and nitrogen sources) is important to achieve maximal EPS production. Resutls about the optimum growth environment for EPS production by LAB has been contradictory. These discrepancies in the literature may be attributed to several factors including different ways of EPS isolation [16].

EPS isolation from culture media is a critical and necessary step previous to polysaccharide quantification. Most EPS isolation procedures are tedious and timeconsuming and include the risk of loss of polymer during manipulation, particularly when EPS-producing microorganisms are grown in complex medium, e.g., in the milk system, polysaccharides could coprecipitate with caseins. Furthermore, EPS-producing LAB grown in milk medium produce very low quantities of EPS (in the range of milligrams per litre of medium) in comparison with the values of lactose present in the media at the moment of quantification (in the range of grams per litre of medium). A wide range of methodologies have been published and all of them are different.

In order to select the most suitable method for EPS quantification, the concentration of kefiran in milk and whey was determined. Kefiran is a water-soluble branched glucogalactan containing equal amounts of d-glucose and d-galactose $[20,22]$ produced by kefir grains or microorganisms isolated from them.

Kefir grains consists mainly of LAB, yeast and acetic acid bacteria that are held together by a matrix of protein and polysaccharide $[1,3]$. Kefir grains are able to acidify deproteinised whey, reducing lactose concentration, increasing their weight and producing a soluble polysaccharide [27]. Polysaccharide biosynthesis is generally ascribed to Lactobacillus kefir [30] or Lactobacillus kefiranofaciens [8, 33]. 
In order to select the best procedure to isolate the polysaccharide produced by kefir grains in milk and deproteinised whey, different isolation methodologies were compared.

\section{MATERIALS AND METHODS}

\subsection{Starter culture}

Kefir grains CIDCA AGK1 were obtained from a household in La Plata, Argentina. The grains were maintained at $-20{ }^{\circ} \mathrm{C}$ and were reactivated by successive subcultures in ultra-high temperature (UHT) low fat milk.

\subsection{Chemicals and culture media}

Anthrone, glucose, lactose and thin layer chromatography reagents were obtained from Sigma (St. Louis, MO, USA). Silica gel $\mathrm{G}$ type 60 plates were purchased from Merck (Darmstadt, Germany).

Commercial UHT skim milk, obtained from Sancor (Santa Fe, Argentina) was used to propagate the grains and prepare the DP-whey.

Deproteinised whey (DP-whey) was prepared by adjusting skim milk to $\mathrm{pH} 4.6$ with $\mathrm{HCl} 2 \mathrm{~mol} \cdot \mathrm{L}^{-1}$ and then heated for $30 \mathrm{~min}$ at $100{ }^{\circ} \mathrm{C}$ and filtered (Whatman No.1 paper). The resulting supernatant was adjusted to pH 6.8 with $\mathrm{NaOH} 2 \mathrm{~mol} \cdot \mathrm{L}^{-1}$, heated for $30 \mathrm{~min}$ at $100{ }^{\circ} \mathrm{C}$ and filtered again to obtain DP-whey. The resulting DP-whey was sterilised at $121^{\circ} \mathrm{C}$ for $15 \mathrm{~min}$. DP-whey composition obtained by this procedure was as follows: $53.4 \pm 3.1 \mathrm{~g} \cdot \mathrm{L}^{-1}$ lactose determined by the anthrone method [29], $3.19 \pm 0.25 \mathrm{~g} \cdot \mathrm{L}^{-1}$ of total nitrogen expressed as protein and $2.74 \pm 0.06 \mathrm{~g} \cdot \mathrm{L}^{-1}$ of non-protein-nitrogen expressed as protein equivalent (conversion factor: 6.38) determined by the Kjeldahl method according to IDF standard $20 \mathrm{~B}$ [14].

\subsection{Culture conditions: whey and milk fermentation}

Kefir grains CIDCA AGK1 were washed with sterile water and inoculated into $100 \mathrm{~mL}$ of skim milk and DP-whey at $10 \%$. After incubation at $20{ }^{\circ} \mathrm{C}$ for $96 \mathrm{~h}$, the grains were separated from the fermented products by filtration through a plastic sieve (sanitised by immersion in $70 \%$ ethanol and then washed with sterile water) and washed prior to the next culture passage (subculture).

\subsection{Isolation and quantification of exopolysaccharide}

After removal of kefir grains by filtration, polysaccharide production in fermented DP-whey and fermented skim milk was determined.

Fermented milk was separated in two aliquots (A and B). Sample A was heated in a boiling water bath for $15 \mathrm{~min}$ in order to dissolve the polysaccharide attached to cells and to inactivate the enzymes that could hydrolyse the polymer. Cells were removed by centrifugation at $10000 \mathrm{~g}$ for $15 \mathrm{~min}$ at $20^{\circ} \mathrm{C}$ in a Sorvall RC-5B plus centrifuge (Sorvall Products, L.P. Newtown, CT, USA). Part of the fermented milk (sample B) was analysed without heat treatment in order to study the effect of heat treatment on polysaccharide recovery. Fermented whey (sample C) was processed according to the methodology applied to sample A. Samples A, B and C were processed by the following 8 methods. Each method was performed at least twice, and the same procedure was carried out on uninoculated media (control without fermentation).

\section{Method 1}

Polysaccharide in samples A, B and C was precipitated by the addition of two volumes of cold $\left(-20^{\circ} \mathrm{C}\right) 96^{\circ}$ ethanol and maintained at $-20{ }^{\circ} \mathrm{C}$ for $24 \mathrm{~h}$. Then, samples were centrifuged at $10000 \mathrm{~g}$ for $15 \mathrm{~min}$ at $4{ }^{\circ} \mathrm{C}$ and pellets were resuspended in hot distilled water. 


\section{Method 2}

This EPS isolation procedure was based on that described by Van Geel-Schutten et al. [31]. Polysaccharide in samples A, B and $\mathrm{C}$ was precipitated by the addition of two volumes of cold ethanol and maintained at $-20{ }^{\circ} \mathrm{C}$ for $24 \mathrm{~h}$. Then, samples were centrifuged at $10000 \mathrm{~g}$ for $15 \mathrm{~min}$ at $4{ }^{\circ} \mathrm{C}$. Pellets were resuspended in hot water and precipitated again by the addition of two volumes of cold ethanol. After storage at $-20{ }^{\circ} \mathrm{C}$ for $24 \mathrm{~h}$ and centrifugation $\left(10000 \mathrm{~g}, 15 \mathrm{~min}, 4^{\circ} \mathrm{C}\right)$, EPS pellets were resuspended in hot distilled water.

\section{Method 3}

This EPS isolation procedure was based on that described by Cerning et al. [5].

Polysaccharide in samples A, B and C was precipitated by the addition of two volumes of cold ethanol and maintained at $-20{ }^{\circ} \mathrm{C}$ for $24 \mathrm{~h}$. Then, samples were centrifuged at $10000 \mathrm{~g}$ for $15 \mathrm{~min}$ at $4{ }^{\circ} \mathrm{C}$. EPS pellets were resuspended in hot water and dialysed (molecular weight cut-off (WMCO) for the dialysis membranes: 1 000, (Spectra/Por, The Spectrum Companies, Gardena, CA, USA)) for $48 \mathrm{~h}$ at $4{ }^{\circ} \mathrm{C}$ against four changes of twice-distilled water.

Methods 4, 5 and 6 were based on that described by Marshall et al. [19].

\section{Method 4}

Samples A, B and C were dialysed (MWCO for the dialysis membranes, 1000 , Spectra/Por) for $48 \mathrm{~h}$ at $4{ }^{\circ} \mathrm{C}$ against four changes of twice-distilled water.

\section{Method 5}

Samples A, B and C were dialysed (MWCO for the dialysis membranes, 6000 to 8000 , Spectra/Por) for $48 \mathrm{~h}$ at $4{ }^{\circ} \mathrm{C}$ against four changes of twicedistilled water.

\section{Method 6}

Samples A, B and C were dialysed (MWCO for the dialysis membranes,
12000 to 14000 , Spectra/Por) for $48 \mathrm{~h}$ at $4{ }^{\circ} \mathrm{C}$ against four changes of twicedistilled water.

\section{Method 7}

This EPS isolation procedure was based on that described by Gancel and Novel [9]. $100 \mu \mathrm{L}$ of a $10 \%$ trypsin (Sigma Chemical Co., St. Louis, USA) solution was added to $10 \mathrm{~mL}$ of A, B and C samples, and the mixture was incubated for $1 \mathrm{~h}$ at $37^{\circ} \mathrm{C}$. Following protein digestion, $250 \mu \mathrm{L}$ of $80 \%$ trichloroacetic acid (TCA) (Merck, Darmstadt, Germany) was added and samples were mixed and stored at $4{ }^{\circ} \mathrm{C}$ for $24 \mathrm{~h}$ and then centrifuged $(8000 \mathrm{~g}$ for $20 \mathrm{~min}$ at $15^{\circ} \mathrm{C}$ ) to remove cells and protein. The supernatant was dialysed (MWCO 1000 ) for $48 \mathrm{~h}$ at $4{ }^{\circ} \mathrm{C}$ against four changes of twice-distilled water.

\section{Method 8}

This EPS isolation procedure was based on that described by Lemoine et al. [18].

The removal of proteins and bacteria from $10 \mathrm{~mL}$ of $\mathrm{A}, \mathrm{B}$ and $\mathrm{C}$ samples was achieved by the addition of $1 \mathrm{~mL}$ of $80 \%$ trichloroacetic acid. After storage for $24 \mathrm{~h}$ at $4{ }^{\circ} \mathrm{C}$, mixtures were centrifuged (10 $\left.000 \mathrm{~g}, 20 \mathrm{~min}, 4^{\circ} \mathrm{C}\right)$. Then, the same volume of acetone (Merck Química Argentina, Buenos Aires, Argentina) was added to the supernatant fraction to precipitate the EPS, which was finally collected by centrifugation $\left(10000 \mathrm{~g}, 20 \mathrm{~min}, 4^{\circ} \mathrm{C}\right)$. Such precipitated EPS fractions were dissolved in distilled hot water and dialysed (MWCO 1000) for $48 \mathrm{~h}$ against four changes of twice-distilled water.

In all cases, total sugars from final solutions were determined by the anthrone method, measuring absorbance at $620 \mathrm{~nm}$ and using glucose and lactose solutions as standards [29]. The values shown in Table I for EPS were calculated by subtracting the amount of background interference in uninoculated media $\left(\leq 4.7 \mathrm{mg} \cdot \mathrm{L}^{-1}\right.$, in methods 2 to 8 ) from the amount detected in fermented broth. 
Table I. Polysaccharide concentration and lactose determination in fermented milk and fermented whey processed by different methodologies.

\begin{tabular}{ccccccc}
\hline $\begin{array}{c}\text { EPS } \\
\text { isolation } \\
\text { methods }\end{array}$ & $\begin{array}{c}\text { Fermented milk with } \\
\text { heat treatment } \\
\text { (Sample A })\end{array}$ & $\begin{array}{c}\text { Fermented milk without } \\
\text { heat treatment } \\
(\text { Sample B })\end{array}$ & $\begin{array}{c}\text { Fermented whey with } \\
\text { heat treatment } \\
\text { (Sample C) }\end{array}$ \\
\hline $\begin{array}{c}\text { Polysaccharide } \\
\left(\mathrm{mg} \cdot \mathrm{L}^{-1}\right)\end{array}$ & Lactose & $\begin{array}{c}\text { Polysaccharide } \\
\left(\mathrm{mg} \cdot \mathrm{L}^{-1}\right)\end{array}$ & $\begin{array}{c}\text { Lactose } \\
\text { Polysaccharide } \\
\left(\mathrm{mg} \cdot \mathrm{L}^{-1}\right)\end{array}$ & Lactose \\
\hline Method 1 & $645 \pm 9^{*}$ & + & $685 \pm 10^{*}$ & + & $425 \pm 2^{*}$ & + \\
Method 2 & $204 \pm 9^{\mathrm{a}}$ & - & $94 \pm 5^{\mathrm{c}, \mathrm{d}}$ & - & $234 \pm 2^{\mathrm{a}}$ & - \\
Method 3 & $218 \pm 6^{\mathrm{a}}$ & - & $114 \pm 8^{\mathrm{c}}$ & - & $242 \pm 12^{\mathrm{a}}$ & - \\
Method 4 & $225 \pm 19^{\mathrm{a}}$ & - & $86 \pm 8^{\mathrm{d}, \mathrm{e}}$ & - & $266 \pm 20^{\mathrm{a}}$ & - \\
Method 5 & $224 \pm 10^{\mathrm{a}}$ & - & $77 \pm 2^{\mathrm{d}, \mathrm{e}, \mathrm{f}}$ & - & $244 \pm 9^{\mathrm{a}}$ & - \\
Method 6 & $133 \pm 3^{\mathrm{b}}$ & - & $70 \pm 5^{\mathrm{d}, \mathrm{e}, \mathrm{f}}$ & - & $158 \pm 5^{\mathrm{b}}$ & - \\
Method 7 & $109 \pm 1^{\mathrm{b}}$ & - & $62 \pm 4^{\mathrm{e}, \mathrm{f}}$ & - & $166 \pm 38^{\mathrm{b}}$ & - \\
Method 8 & $118 \pm 9^{\mathrm{b}}$ & - & $60 \pm 10^{\mathrm{f}}$ & - & $77 \pm 6^{\mathrm{c}}$ & \\
\hline
\end{tabular}

* Total content of carbohydrates (lactose + EPS).

+: Lactose detected by TLC.

-: Lactose not detected by TLC.

$\mathrm{a}, \mathrm{b}, \mathrm{c}, \mathrm{d}, \mathrm{e}, \mathrm{f}$ Means for each parameter without a common superscript are significantly different $(P \leq 0.05)$. Samples A and B were analysed independently from sample C. Values are means \pm SD for at least 2 independent experiments. Methods 1 to 8 correspond to the ones described in Materials and Methods.

All the samples were tested for the absence of lactose by qualitative thin layer chromatography (TLC) on Silica gel G type 60 plates using $n$-propanol-acetic acid-water (70:20:10) as running solvent. TLC plates were developed with $p$-amino benzoic acid $7 \mathrm{~g} \cdot \mathrm{L}^{-1}$ and $o$-phosphoric acid $30 \mathrm{~g} \cdot \mathrm{L}^{-1}$ in methanol [35].

\subsection{Statistical analysis}

Differences in polysaccharide concentration were tested for significance by analysis of variance (ANOVA). Differences were considered at $P \leq 0.05$.

\section{RESULTS}

Sixteen different procedures for exopolysaccharide isolation from fermented milk were studied: eight of them included an initial heat treatment step (sample A) and the other eight procedures did not include heat treatment (sample B).
Table I shows that EPS recovery from culture media depended strongly on the EPS isolation method. EPS isolation procedures that contained a heat treatment step produced a significantly higher EPS recovery than those without heat treatment $(P \leq 0.05)$. Polysaccharide concentration quantified after isolation procedures without heat treatment (sample B) was only 34 to $56 \%$ of polysaccharide quantified after isolation procedures with heat treatment (sample A), depending on the method used. Taking into account these results, exopolysaccharide in fermented whey was isolated by methodologies that contained heat treatment as the first step (sample C). The results obtained with sample $\mathrm{C}$ are shown in Table I.

Polysaccharide separation from fermented milk and whey (Tab. I) by method 1 , that included a unique step of ethanol precipitation, was not adequate for polysaccharide isolation and quantification because residual lactose co-precipitated with EPS (Tab. I). Consequently, total carbohydrates measured 
by anthrone method resulted in a false high EPS value. An additional step of ethanol precipitation and methodologies that included a final step of dialysis achieved the elimination of residual lactose (Tab. I).

Ethanol precipitation steps in method 2 were performed at two temperatures. Assays performed at $-20^{\circ} \mathrm{C}$ (temperature selected for all the experiments) gave the same EPS recovery $(P \leq 0.05)$ as those obtained when ethanol precipitation was performed at $4{ }^{\circ} \mathrm{C}$, temperature usually used in literature (data not shown)

Methods that contained two steps of ethanol precipitation (method 2), one step of ethanol precipitation followed by dialysis (method 3 ) or direct dialysis with membranes of molecular weight cut-off lower than 6000 to 8000 (methods 4 and 5) gave values of polysaccharide concentration that were not significantly different $(P \leq 0.05)$ when they were applied to sample A or sample C (Tab. I). In consequence, these methods were considered equivalent and the average polysaccharide concentration of samples $\mathrm{A}$ and $\mathrm{C}$ obtained with methods 2 to 5 , was $218 \pm 9 \mathrm{mg} \cdot \mathrm{L}^{-1}$ and $247 \pm$ $13 \mathrm{mg} \cdot \mathrm{L}^{-1}$, respectively.

These results were significantly higher $(P \leq 0.05)$ than those obtained with methods that contained a TCA precipitation step (methods 7 and 8) or direct dialysis with membranes of molecular weight cut-off of 12000 to 14000 (method 6).

\section{DISCUSSION}

Selection of an adequate EPS isolation method is a critical step previous to EPS quantification. For EPS isolation, many authors used one or more steps of selective EPS precipitation by adding one, two or more volumes of cold ethanol $[7,11,26$, 31-34]; others used the same procedure with a final step of dialysis $[2,5,20,21,25$, 30]. Other researchers preferred a step of TCA precipitation to remove contaminating material (proteins, polypeptides) combined with a final step of dialysis $[9,16]$. GarciaGaribay and Marshall [10] used TCA precipitation and selective EPS precipitation by adding three volumes of cold ethanol. Some authors combined TCA precipitation, selective EPS precipitation with acetone or cold ethanol and dialysis [12, 13, 17, 18, 28]. Marshall et al. [19] used only a step of dialysis previous to EPS quantification. Some of the discrepancies in EPS production by LAB may be attributed to different means of EPS isolation [16].

The present results show that polysaccharide quantified in milk and deproteinised whey fermented with kefir grains strongly depended on the isolation methodology used.

Heat treatment of the samples as a first step in the polysaccharide isolation procedure is critical for complete recovery of the EPS. Samples without this step gave lower polysaccharide concentration than those including this treatment (Tab. I). This fact could be ascribed to the separation and dissolution of polysaccharide attached to cell wall and milk proteins. Besides, heat treatment allowed the inactivation of enzymes potentially capable of degrading the polymer. In the procedures without heat treatment, part of the polysaccharide attached to cells and caseins would be lost with the pellet in the first step of centrifugation.

High false results were obtained when residual lactose was not fully eliminated from the EPS pellet (method 1). Overestimation of EPS concentration also occurs when complex growth media are used for EPS production due to interference from medium components [15]. Milk and whey are convenient as growth media for EPS production because controls without fermentation gave minimal interference background $\left(\leq 4.7 \mathrm{mg} \cdot \mathrm{L}^{-1}\right)$.

Several isolation methods led to a false low result, since some polysaccharide was lost in one of the isolation steps. TCA precipitation of contaminating materials such as proteins or polypeptides from cultures had the advantage of obtaining a 
purer polysaccharide. However, a great proportion of the EPS (about 50\%) coprecipitated with TCA. This fact would explain why techniques that contained a step of TCA precipitation (methods 7 and 8) gave polysaccharide values lower than those that did not include TCA precipitation. Hence, these methods would require washing the TCA precipitate at least once for a complete EPS recovery. When the final objective is polysaccharide quantification, a complete purification of the sample is not necessary since protein contamination does not interfere with anthrone determination. On the other hand, when a purified polysaccharide is necessary, for example, when the aim of the work is polysaccharide characterisation, a step of TCA precipitation may be more appropriate.

Direct dialysis with MWCO 12000 to 14000 membranes (method 6) gave a lower polysaccharide concentration than methods that used membranes with molecular weight cut-off lower than 8000 . EPS produced by lactic acid bacteria have apparent molecular masses that range from $1 \times 10^{4}$ to $>1 \times 10^{6} \mathrm{~g} \cdot \mathrm{mol}^{-1}$ [4]. Therefore the low value obtained could be ascribed to the lost of a fraction of low molecular weight (lower than 12 000) in the dialysis water.

Ethanol precipitation done twice (method 2), direct dialysis (methods 4 and 5) or a combination of ethanol precipitation followed by a dialysis step (method 3) provided the same polysaccharide concentration. According to the present results, methods 2 to 5 were the most suitable procedures for isolation of kefir polysaccharide from milk and whey.

\section{ACKNOWLEDGEMENTS}

P.S. Rimada is a research fellow of Universidad Nacional de La Plata (UNLP). A.G. Abraham is a member of the Researcher Career of Consejo Nacional de Investigaciones Científicas y Técnicas (CONICET). The authors are grateful to L.A. Brandi for technical assistance. Agencia Nacional de Promoción Científica y Tecnológica (ANPCyT), CONICET, and Universidad Nacional de La Plata (UNLP) supported this work.

\section{REFERENCES}

[1] Abraham A.G., De Antoni G.L., Characterization of kefir grains grown in cows' milk and in soya milk, J. Dairy Res. 66 (1999) 327-333.

[2] Ariga H., Urashima T., Michihata E., Ito M., Morizono N., Kimura T., Takahashi S., Extracellular polysaccharide from encapsulated Streptococcus salivarius subsp. thermophilus OR 901 isolated from commercial yogurt, J. Food Sci. 57 (1992) 625-628.

[3] Bottazzi V., Zacconi C., Sarra P.G., Dallavalle P., Parisi M.G., Kefir microbiology, chemistry and technology, Ind. Latte 30 (1994) 41-62.

[4] Cerning J., Marshall V.M., Exopolysaccharides produced by the dairy lactic acid bacteria, Recent Res. Dev. Microbiol. 3 (1999) 195-209.

[5] Cerning J., Renard C.M.G.C., Thibault J.F., Bouillanne C., Landon M., Desmazeaud M., Topisirovic L., Carbon source requirements for exopolysaccharide production by Lactobacillus casei CG11 and partial structure analysis of the polymer, Appl. Environ. Microbiol. 60 (1994) 3914-3919.

[6] De Vuyst L., Degeest B., Heteropolysaccharides from lactic acid bacteria, FEMS Microbiol. Rev. 23 (1999) 153-177.

[7] Fialho A.M., Martins L.O., Donval M.L., Leitao J.H., Ridout M.J., Jay A.J., Morris V.J., Sá-correia I., Structures and properties of gellan polymers produced by Sphingomonas paucimobilis ATCC 31461 from lactose compared with those produced from glucose and from cheese whey, Appl. Environ. Microbiol. 65 (1999) 2485-2491.

[8] Fujisawa T., Adachi S., Toba T., Arihara K., Mitsuoka T., Lactobacillus kefiranofaciens sp. nov. isolated from kefir grains, Int. J. Syst. Bacteriol. 38 (1988) 12-14.

[9] Gancel F., Novel G., Exopolysaccharide production by Streptococcus salivarius subsp. thermophilus cultures. 1. Conditions of production, J. Dairy Sci. 77 (1994) 685-688.

[10] García-Garibay M., Marshall V.M.E., Polymer production by Lactobacillus delbrueckii subsp. bulgaricus, J. Appl. Bacteriol. 70 (1991) 325-328. 
[11] Gassem M.A., Schmidt K.A., Frank J.F., Exopolysaccharide production from whey lactose by fermentation with Lactobacillus delbrueckii subsp. bulgaricus, J. Food Sci. 62 (1997) 171-173.

[12] Grobben G.J., Sikkema J., Smith M.R., de Bont J.A.M., Production of extracellular polysaccharides by Lactobacillus delbrueckii subsp. bulgaricus NCFB 2772 grown in a chemically defined medium, J. Appl. Bacteriol. 79 (1995) 103-107.

[13] Gruter M., Leeflang B.R., Kuiper J., Kamerling J.P., Vliegenthart F.G., Structural characterisation of the exopolysaccharide produced by Lactobacillus delbruckii subsp. bulgaricus RR grown in skimmed milk, Carbohyd. Res. 239 (1993) 209-226.

[14] IDF, Milk determination of nitrogen content, Standard 20B, Int. Dairy Fed., Brussels, Belgium,1993.

[15] Kimmel S.A., Roberts R.F., Development of a growth medium suitable for exopolysaccharide production by Lactobacillus delbrueckii subsp. bulgaricus RR, Int. J. Food Microbiol. 40 (1998) 87-92.

[16] Kimmel S.A., Roberts R.F., Ziegler G.R., Optimization of exopolysaccharide production by Lactobacillus delbrueckii subsp. bulgaricus RR grown in a semidefined medium, Appl. Environ. Microbiol. 64 (1998) 659-664.

[17] Knoshaug E.P., Ahlgren J.A., Trempy J.E., Growth associated exopolysaccharide expression in Lactococcus lactis subsp. cremoris ropy 352, J. Dairy Sci. 83 (2000) 633-640.

[18] Lemoine J., Chirat F., Wieruszeski J.M., Strecker G., Favre N., Neeser J.R., Structural characterization of the exocellular polysaccharides produced by Streptococcus thermophilus SFi39 and SFi12, Appl. Environ. Microbiol. 63 (1997) 3512-3518.

[19] Marshall V.M., Cowie E.N., Moreton R.S., Analysis and production of two exopolysaccharides from Lactococcus lactis subsp. cremoris LC330, J. Dairy Res. 62 (1995) 621-628.

[20] Micheli L., Uccelletti D., Palleschi C., Crescenzi V., Isolation and characterisation of a ropy Lactobacillus strain producing the exopolysaccharide kefiran, Appl. Microbiol. Biotechnol. 53 (1999) 69-74.

[21] Mozzi F., De Giori G.S., Oliver G., De Valdez G.F., Effect of culture $\mathrm{pH}$ on the growth characteristics and polysaccharide production by Lactobacillus casei, Milchwissenschaft 49 (1994) 667-670.
[22] Mukai T., Toba T., Itoh T., Adachi S., Structural microheterogeneity of kefiran from kefir grains, Jpn. J. Zootech. Sci. 59 (1988) 167-176.

[23] Nagaoka M., Hashimoto S., Watanabe T., Yokokura T., Mori Y., Anti-ulcer effects of lactic acid bacteria and their cell-wall polysaccharides, Biol. Pharm. Bull. 17 (1994) 1012-1017.

[24] Oda M., Hasegawa H., Komatsu S., Kambe M., Tsuchiya F., Anti-tumor polysaccharide from Lactobacillus sp., Agric. Biol. Chem. 47 (1983) 1623-1625.

[25] Petry S., Furlan S., Crepeau M.-J., Cerning J., Desmazeaud M., Factors affecting exocellular polysaccharide production by Lactobacillus delbrueckii subsp. bulgaricus grown in a chemically defined medium, Appl. Environ. Microbiol. 66 (2000) 3427-3431.

[26] Pidoux M., Marshall V.M., Zanoni P., Brooker B., Lactobacilli isolated from sugary kefir grains capable of polysaccharide production and minicell formation, J. Appl. Bacteriol. 69 (1990) 311-320.

[27] Rimada P.S., Abraham A.G., Polysaccharide production by kefir grains during whey fermentation, J. Dairy Res. 68 (2001) 653-661.

[28] Robijn G.W., van den Berg D.J.C., Haas H., Kamerling J.P., Vliegenthart J.F.G., Determination of the structure of exopolysaccharide produced by Lactobacillus sake 0-1, Carbohyd. Res. 276 (1995) 117-136.

[29] Southgate D.A.T., Selected methods, in: Southgate D.A.T. (Ed.), Determination of food carbohydrates, Elsevier, Applied Science, London, UK, 1991, pp. 99-144.

[30] Toba T., Arihara K., Adachi S., Comparative study of polysaccharides from kefir grains, an encapsuled homofermentative Lactobacillus species and Lactobacillus kefir, Milchwissenschaft 42 (1987) 565-568.

[31] van Geel-Schutten G.H., Flesch F., ten Brink B., Smith M.R., Dijkhuizen L., Screening and characterization of Lactobacillus strains producing large amounts of exopolysaccharides, Appl. Microbiol. Biotechnol. 50 (1998) 697-703.

[32] van Geel-Schutten G.H., Faber E.J., Smit E., Bonting K., Smith M.R., ten Brink B., Kamerling J.P., Vliegenthart J.F.G., Dijkhuizen L., Biochemical and structural characterization of the glucan and fructan exopolysaccharides synthesized by the $\mathrm{Lac}$ tobacillus reuteri wild-type and by mutant strains, Appl. Environ. Microbiol. 65 (1999) 3008-3014. 
[33] Yokoi H., Watanabe T., Fujii Y., Toba T., Adachi S., Isolation and characterization of polysaccharide-producing bacteria from kefir grains, J. Dairy Sci. 73 (1990) 1684-1689.

[34] Yokoi H., Watanabe T., Optimum culture conditions for production of kefiran by
Lactobacillus sp. KPB-167B isolated from kefir grains, J. Ferment. Bioeng. 74 (1992) 327-329.

[35] Zweig G., Sherma J., Handbook Series in Chromatography, Section A: General Data and Principles Volume II, CRC Press Inc., Boca Raton, USA, 1978, pp. 124-130. 